8 September, 1987

Dr. A.J. Kayll

President

Canadian Institute of Forestry

Dear Jim,

The Prime Minister has asked me to respond to your predecessor's letter of March 16, regarding declining employment opportunities for graduating foresters.

I share the concerns raised in the letter written by Mr. J.W. Toovey, in which the need to establish a national forest internship program was discussed. As you know, since this correspondence was initiated a Forest Industry Internship Program has been established. The program represents a unique undertaking which involves the Canadian Forestry Service, Employment and Immigration Canada and the Canadian Pulp and Paper Association (CPPA).

This two-year pilot project is designed to assist unemployed and under-employed university, forestry school and technical school graduates to find meaningful employment. The program will provide forest work experience/training opportunities and will ensure that candidates' skills are not otherwise lost to the forest sector as a result of the downturn in economic conditions during the past few years.
As we discussed at the CIF Annual Meeting in St. John's, Newfoundland, recently, it is my hope that the success of this pilot project will lead to a larger undertaking in the future. The continued support of the private sector, professional and academic communities is the key.

I want to thank the CIF for its continued support in developing programs and providing advice in the pursuit of an even stronger forest sector in Canada.

Yours sincerely,

Gerald S. Merrithew Minister of State Forestry and Mines

October 21, 1987

Dr. J.R. Carrow

Past-President, CIF

\section{Dear Dr. Carrow:}

Thank your for your letter of August 11 th regarding export taxes on softwood lumber. I apologize for the delay in replying.

I would like to assure you that we are aware of the needs of the forest industry, and of the specific circumstances created by the export tax. It is not general government policy to designate revenues for specific purposes, as suggested in the resolution endorsed by your Institute. However, the Ministry of Natural Resources has again been provided with significant additional funds. Its budget has been increased this year by 20 per cent, or about $\$ 34$ million.

At the same time, $\$ 5$ million has been made available to establish a Northern Forest Biology Centre and Research Chair at Lakehead University. Also, you may be aware that the Northern Ontario Heritage Fund is now being put into operation. The Fund has an initial allocation of $\$ 30$ million, and full consideration will be given to project proposals from the forestry sector that promise to generate employment in Northern Ontario.

I have asked my colleague, the Honourable Vincent Kerrio, Minister of Natural Resources, and others to investigate other initiatives of benefit to the forest industry, and part of this effort will involve looking into the possibility of further government support for forestry education and research.

I appreciate having the benefit of your views, and have sent a copy of your letter to Mr. Kerrio, and to the Honourable Robert Nixon, Treasurer and Minister of Economics, who will also be interested in your comments.

Sincerely, David Peterson The Premier of Ontario

\title{
LOST MEMBERS
}

$\begin{array}{lllrlr}\text { Adamson, T.B.A. } & \text { RM } & \text { Harder, James L. } & \text { SO } & \text { Pollock, Alan J. } & \text { RM } \\ \text { Berry, John } & \text { NO } & \text { Horner, lan J. } & \text { SK } & \text { Powell, John M. } \\ \text { Boutilier, P.J. } & \text { RM } & \text { Kind, R.G. } & \text { VI } & \text { Sacino, Don } & \text { RM } \\ \text { Bowers, Charles } & \text { NS } & \text { MacLellan, John G. } & \text { NS } & \text { Smart, Brian R. } \\ \text { Dearman, M.A. } & \text { OV } & \text { McGill, Steven J. } & \text { NW } & \text { Smith, B.C. } & \text { OV } \\ \text { Dolsen, Dana E. } & \text { RM } & \text { Middlemiss, John W. } & \text { OV } & \text { Li, Wenda } & \text { NW } \\ \text { Ewing, W.D. } & \text { VA } & \text { Moore, T.G.E. } & \text { MR } & \text { Wilson, Richard } & \text { OV } \\ \text { Girous, Emile Jr. } & \text { SO } & \text { Newfeld, David S. } & \text { MB } & & \end{array}$

